http://ejournal.upi.edu/index.php/jaz - e-mail: jurnal.zonasi@gmail.com dan jurnal_zonasi@upi.edu doi.org/10.17509/jaz.v3i1.17858

\title{
REVITALISASI PASAR PRAWIROTAMAN MENJADI PASAR KREATIF DENGAN PENDEKATAN ARSITEKTUR KONTEKSTUAL SEBAGAI KONSEP DESAIN
}

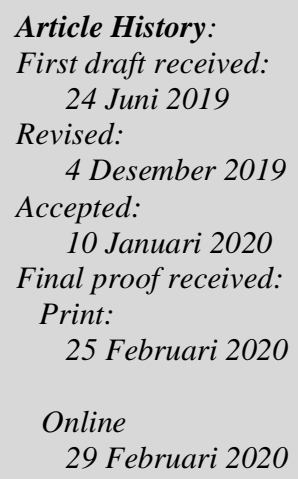

\author{
Aldi Kurnia ${ }^{1}$; Muhammad Arief Kurniawan ${ }^{2}$ \\ ${ }^{1}$ Arsitektur, Fakultas Sains dan Teknologi, Universitas Teknologi Yogyakarta, Jalan \\ Glagahsari No.63, Yogyakarta \\ 2 Program S2 Arsitektur dan Perencanaan, Fakultas Teknik, Universitas Gajah Mada, Jalan \\ Grafika 2 Sentolowo, Yogyakarta \\ Email: Adhirya5621@gmail.com
}

\begin{abstract}
Revitalization of Prawirotaman Market through Contextual Architecture to Become a Creative Market is to redesign a building, which functions as a purchase and sale area with such commodities as basic needs, food, vegetables, glassware, and others. The redesign is motivated by a number of problems, such as the many inefficient and ineffective spaces, lack of sale areas, and minimum parking lots. In addition, it will improve the market status from a traditional market to a Class II market. The growing population and location of Prawirotaman market that is close to tourist accommodations and tourism village provide an opportunity for the market to operate 24 hours, particularly as a culinary market. To revitalize Prawirotaman Market, the author applies the concept of Contextual Architecture as a creative market. Such approach aims to create a new atmosphere, especially in Prawirotaman Village, to make it better known as a market with a contextual concept as a creative market. The revitalization of Prawirotaman Market to solve a number of problems is conducted by analyzing the problems, planning the design concept, and analyzing the results to obtain the proper concept and response.
\end{abstract}

Keywords: Social relationship, Space Problem, Traditional

\begin{abstract}
Abstrak: Revitalisasi Pasar Prawirotaman Dengan Pendekatan Arsitektur Kontekstual Sebagai Pasar Kreatif adalah perancangan kembali sebuah bangunan yang berfungsi sebagai tempat jual beli dengan jenis barang dagang meliputi kebutuhan pokok, makanan, sayuran, barang pecah belah dan masih banyak lagi. Perencanaan ulang ini dilatar belakangi oleh beberapa permasalahan seperti banyak ruang yang tidak efisien dan efektif, kurangnya tempat berdagang, kurangnya lahan parkir, selain itu akan meningkatkan status pasar menjadi pasar tradisional menjadi tingkat kelas II. Pertumbuhan penduduk yang semakin bertambah dan lokasi Pasar Prawirotaman berdekatan dengan kampung turis atau kampung wisata yang mampu menjadi peluang untuk menjadikan pasar ini beroperasi selama 24 jam terutama di bidang kulinernya. Dalam merevitalisasi Pasar Prawirotaman penulis menerapkan konsep dengan " Pendekatan Arsitektur Kontekstual sebagai pasar kreatif " Pemilihan pendekatan ini bertujuan untuk menciptakan suasana baru khususnya di kampung prawirotaman supaya menjadi lebih dikenal lagi oleh masyarakat sebagai pasar yang memiliki konsep kontekstual sebagai pasar kreatif. Solusi yang diterapkan dalam Revitalisai Pasar Prawirotaman untuk mengatasi semua permasalahan yang timbul dengan cara menganalisa permasalahan kemudian membuat konsep perancangan yang setiap hasil analisisnya mendapatkan konsep dan responnya masing - masing.
\end{abstract}

Kata Kuunci : Hubungan dengan masyarakat, Permasalahan Ruang, Tradisional

\section{Pendahuluan}

Pasar merupakan bagian intim dalam kehidupan masyarakat karena merupakan sebuah tempat dimana segala sesuatu kebutuhan sehari-hari yang dibutuhkan manusia bias ditemukan disana. Contonya saja pasar tradisional yang sudah dikenal bahkan sudah ada sejak masa penjajahan dahulu. Oleh sebab itu penataan, funsi, kelayakan, serta keamanan merupakan bagian yang penting guna membuat kenyamanan saat terjadinya 
transaksi tersebut, salahsatu pasar yang akan saya bahas dan melakukan perancangan ulang yaitu Pasar Prawirotaman yang berada di Kota Yogyakarta.

Sejarah singkat Pasar Prawirotaman menutut : (Adrianto, 2004) Merupakan kampung yang berada sekitar 5 kilometer dari pusat Kota Yogyakarta. Kawasan Kampung Prawirotaman dikenal sebagai kampung wisata internasional, selain Kampung Sosrowijayan. Berdirinya kampung ini memiliki sejarah yang panjang. Wajah kampung yang bermula sebagai kampung budaya (kerajinan batik, tenun), kemudian beralih ke industri pariwisata (perhotelan), merupakan sebuah kreativitas para penghuninya untuk tetap bertahan sebagai pelaku ekonomi mandiri. Sekarang kampung Prawirotaman telah berkembang sedemikian rupa dan mendapatkan predikat sebagai kampung internasional.

Perencanaan Pasar Prawirotaman dilakukan dengan merevitalisasi bangunan yang sudah ada. Menurut (Mentri, 2010) tentang Revitalisasisi Kawasan adalah salah satu upaya untuk menghidupkan kembali kawasan mati, yang pada masa silam pernah hidup, atau mengendalikan dan mengembangkan kawasan untuk menemukan kembali potensi yang dimiliki oleh sebuah kota sehingga diharapkan dapat memberikan peningkatan kualitas lingkungan kota yang pada akhirnya berdampak pada kualitas hidup dari penghuninya.

Revitalisasi merupakan upaya untuk memvitalkan kembali suatu kawasan atau bagian kota yang dulunya pernah vital atau hidup akan tetapi kemudian mengalami kemunduran atau degradasi. Gejala penurunan kualitas fisik ruang kota dapat dengan mudah diamati pada kawasan kota bersejarah atau tua, karena sebagai bagian dari perjalanan sejarah (pusat kegiatan perekonomian dan sosial budaya), kawasan kota tersebut umumnya berada dalam tekanan atau pengaruh pembangunan. Proses revitalisasi sebuah kawasan atau bagian kota mencakup perbaikan aspek fisik dan aspek ekonomi dari bangunan maupun ruang kota. Paper ini mencoba melihat sejauhmana peran intervensi fisik dalam kegiatan revitalisasi kawasan ruang kota (Hantono, Butudoka, Prakoso, dan Yulisaksono, 2019). Mengingat citra kawasan sangat erat kaitannya dengan kondisi visual kawasan, khususnya dalam menciptakan kegiatan atau fungsi baru, menarik kegiatan dan pengunjung, intervensi fisik ini perlu dilakukan. Beberapa isu yang menjadi penekanan dalam pembahasan ini yaitu strategi revitalisasi yang dilihat dari isu lingkungan (environmental sustainability), rehabilitasi kegiatan ekonomi informal dan formal serta kegiatan tersebut harus berdampak positif serta dapat meningkatkan dinamika dan kehidupan sosial masyarakat atau warga yang selanjutnya dinamakan dengan revitalisasi sosial atau intitusional.

Perancangan Pasar Prawirotaman ini didasarkan dengan arsitektur kontekstual sebagai pasar kreatif. Menurut (C.Poetics, 1992), klasifikasi dari bidang konteks dalam arsitektur dapat berhubungan dengan site dari lingkungan,kondisi bangunan sekitar, masyarakat, budaya, dan material didaerah setempat. Arsitektur kontekstual merupakan salah satu prinsip perancangandalam arsitektur yang mempertimbangkan permasalahan desaindalam beberapa atau kesatuan bidang konteks arsitektural. Menurut Anthony $\mathrm{C}$ Antonades, klasifikasi dari bidang konteks dalam arsitektur dapat berhubungan dengan site dari lingkungan, kondisi bangunan sekitar, masyarakat, budaya, dan material daerah setempat. Tujuan klasifikasi ini guna mengarahkan desain dalam perancangan (Ischak, Setioko, dan Gandarum, 2018).

(Antoniades A. C., 1992) Kontekstual merupakan suatu hubungan antara arsitektur dansitenya, berkaitan dengan lingkungan sekitarnya denganmemperhatikan kondisi bangunan sekitar, dimana masyarakat,budaya, area, dan materialnya berasal dari tempat arsitekturitu akan dibangun

Menurut buku (Alan), ada 7 poin penting untuk design yang responsif dalam perencanaan aritektur kontekstual adalah : 1) Permeability, kemudahan akses dan sirkulasi. 2) Variety, ada beberapa fungsi berbeda dalam satu bangunan atau satu kawasan. 3) Legibility, ada bentukan yang mudah diidentikasi dan membantu kemudahan orientasi. 4) Robustness, ada ruang-ruang temporal, dapat difungsikan untuk berbagai aktivitas yang berbeda pada waktu yang berbeda. 5) Richness, kekayaan rasa dan pengalaman melalui perbedaan material, susunan ruang, dll. 6) Visual Appropriate, mampu mengidentifikasi fungsi bangunan dengan melihat fisiknya, sekolah tampak seperti sekolah, rumah sakit seperti rumah sakit, mall seperti mall. 7) Personalization, melibatkan partisipasi komunitas serta adanya interaksi antara manusia dan lingkungan.

(Mattorang, Tinjauan Tentang Arsitektur Kontekstual, 2012) Antara tahun 1880-1890 terjadi revolusi Industri yang berdampak timbulnya sistem fabrikasi di mana sebagian besar elemen bangunan dibuat dipabrik, penggunaan mesin-mesin, teknologi baja tulangan, dsb. Sistem fabrikasi tersebut memungkinkan pembangunan dalam waktu yang relatif singkat. Sejalan dengan hal tersebut maka lahirlah gerakan arsitektur modern. Gaya arsitektur modern muncul sebagai gaya internasional yang cukup memiliki kemiripan di semua tempat, dan hampir di semua negara. Bahkan, bangunan-bangunan yang muncul terkadang tidak memperhatikan kondisi lokal lingkungan sekitar. Bahkan pada masa itu arsitektur modern dikatakan tidak mempunyai ruh. 


\section{Metode Penelitian}

Penelitian ini bertujuan untuk meningkatkan segala kegiatan dan aktifitas yang berkaitan dengan jual beli dan menambah ketertarikan masyarakat luas untuk berbelanja ke pasar tradidional. Peran pasar tradisional yang sangat penting, salah satunya pasar tradisional yang ada di kawasan wisata yaitu di kampong Prawirotaman. Tentunya dengan melakukan penelitian ini akan mampu mengembangkan dibidang ekonomi, dan pastinya juga harus memperhatikan kesesuaian ruang supaya mampu menjadi tempat yang bermanfaat serta tepat. Seperti yang dikutip dalam jurnal (Endy Marlina, 23 June 2012) yaitu "ruang sebagai place dan ruang sebagai space" maknanya pasar bias dilihat dari aspek makna, nilai/ harga dan juga dilihat dari aspek fungsi serta struktur.

Dengan adanya kegiatan ini tentunya juga dilakukan pengumpulan informasi yang dimulai dari mencari tahu isu-isu yang terkait dang berhubungan dalam masalah tersebut. Pengumpulan informasi dapat dilakukan dengan melakukan pengamatan secara langsung seperti wawancara kepada pihak terkait, yang kemudian dilakukan analisis data sehingga besa mendapatkan hasil yang akan di tuju. Tujuannya didapat hasil yang mampu mengubah dan memgembangkan lagi Pasar Prawirotaman tersebut seperti : 1) Penataan ruang luar meliputi, ruang pedestrian, area terbuka hijau, loading dock, dan area parker. 2) Ruang dalam meliputi penataan kios, los, lapak, area parkir, area pengelola, dan area penunjang lainnya. 3) Respon dari konsep perancangan yang digunakan. 4) mengembangkan aktivitas perekonomian dalam dan luar pasar.

Lingkup pembahasan terbagi dalam 2 bagian yaiti arsitektur dan non arsitektur. 1) Lingkup pembahasan arsitektural menitikberatkan pada hal-hal dan permasalahan disekitar ilmu disiplin arsitektur serta hal-hal yang berpengaruh terhadap perencanaan dan perancangan Pasar Prawirotaman, maka perlu adanya lingkup permasalahan arsitektural seperti : Fungsi ruang, Batasan ruang, Komposisi ruang, Komponen ruang, Bentuk ruang, Sirkulasi, Bentuk bangunan, Studi literature tentan Pasar Tradisional, Kajian tentang fasilitas-fasilitas utama dan pendukung Pasar Tradisional, Kajian penggunaan material, Lansekap, Tata masa bangunan, Konseptual perancangan dan perencanaan Pasar Tradisional. 2) Lingkup pembahasan non arsitektural dilakukan dengan mengkaji perkembangan perekonomian yang didukung dengan adanya pasar tradisional, menyelaraskan hubungan manusia dengan bangunan gedung dan fasilitas-fasilitas yang akan dibangun, membahas proses perancangan yang memperhatikan kondisi geografis dan topografis daerah setempat.

Metode yang digunakan untuk merevitalisasi Pasar Prawirotaman bermula dari proses pengolahan data awal sampai akhir dan dilakukan secara bertahap, serta terperinci agar proses desain yang dilakukan dapat berjalan lancar dan menghasilkan desain yang tepat sasaran.

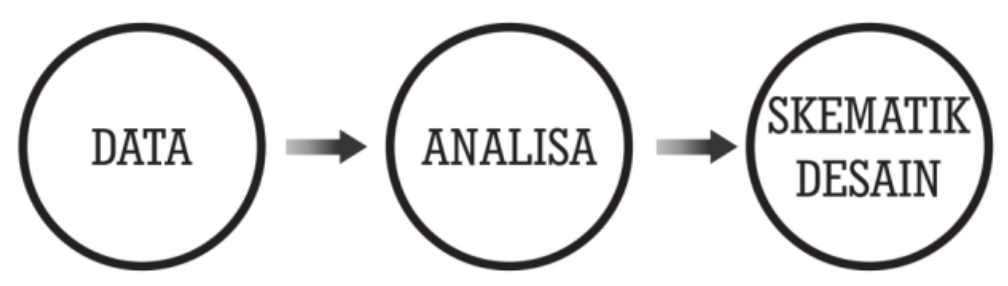

Gambar 1 Bagan Metode Perancangan

Kegiatan ini merupakan sebuah proses yang harus dilakukan supaya mampu menghasillkan recana yang sesuai dengan perencanaan dan terkonsep dengan baik dan benar. Analisis perencanaan dilakukan guna mendapatkan hasil yang memuaskan dalam merevitalisasi Pasar Prawirotaman. Analisis tidak bias dilakukan dengan mengarang data sebab Analisis berhubungan langsung dengngan obyek rancangan yang sesuai dengan tema yang diambil. Arsitektur kontekstual dan proses pencarian bentuk, berisi analisis dan eksplorasi ragam konsep desain yang menunjukkan keterkaitan antara bentuk arsitektur dan konteks lingkungan perkotaan. Pertama, mengambil motif-motif desain setempat, seperti bentuk massa, pola atau irama bukaan, dan ornamen desain yang digunakan.

Arsitektur kontekstual dan proses pencarian bentuk, berisi analisis dan eksplorasi ragam konsep desain yang menunjukkan keterkaitan antara bentuk arsitektur dan konteks lingkungan perkotaan. Pertama, mengambil motif-motif desain setempat, seperti bentuk massa, pola atau irama bukaan, dan ornamen desain yang digunakan.

Analisis tapak dilakukan dengan mengumpulkan data yang menjelaskan konsisi site, kondisi bangunan eksisting, Analisis aksesibilitas, matahari, view, Angin, insfratuktur, dan kebisingan. Dengan hal tersebut diharpkan mampu merancang bangunan yang bias merespon dari hasil Analisis. 
Analisis kegiatan dilakukan setelah kita mengetahui Analisis pelaku untuk mengetahui siapa saja yang ada di dalam Pasar Prawirotaman tersebut dan kemudian akan muncul kebutuhan ruang.

Analisis kebutuhan ruang akan muncul seelah selesai melakukan Analisis kegiatan dan pengguna. Nantinya Analisis kebutuhan ruang akan memunculkan jenis-jenis ruang yang harus ada serta dimensi ruang yang di butuhkan dan sesuai dengan pengguna aktifitas. Analisis kebutuhan ruang mencakup antara kebutuhan dalam dan luar pasar yang nantinya akan berhubungan dengan fungsi, pengelompokan dan zoning di Pasar Prawirotaman tersebut.

Analisis fungsi dimaksudkan supaya ruang-ruang yang adan nantinya dapat berfungsi secara optimal dan tidak menghasilkan ruang yang sia-sia. Analisis fungsi ruang juka berkaitan dengan besar kecilnya dimensi ruang yang akan dibuat, hal ini bertujuan supaya tidak menghasilkan sisa ruang yang berlebih dan kurang besarnya suatu ruang.

\section{Hasil dan Pembahasan}

Pasar memiliki dua peran yaitu penjual dan pembeli. Pasar dapat diartikan sebagai sebuah akses yang membentuk sebuah hubungan sosial dan insfratukur lalu menciptakan adanya barang, jasa serta tenaga kerja untuk orang-orang dengan imbalan uang. Barang dan jasa yang dijual menggunakan alat pembayaran yang sah seperti uang fiat. Dalam ilmu ekonomi arus utama, konsep pasar adalah setiap struktur yang memungkinkan pembeli dan penjual untuk menukar jenis barang, jasa dan informasi. Pertukaran barang atau jasa untuk uang disebut dengan transaksi. Pasar juga diklarifikasian menjadi dua jenis yaitu pasar modern dan tradisional. Pasar tradisonal adalah pasar yang kegiatan para penjual dan pembelinya dilakukan secara langsung dalam bentuk eceran dalam waktu sementara atau tetap dengan tingkat pelayanan terbatas. Pasar Moderen adalah pasar yang bersifat modern yang dimana barang dagangannya diperjual belikan dengan harga yang pas sehingga tidak ada aktivitas tawar menawar dan dengan layanan yang baik.

Dalam perancangan revitalisasi Pasar Prawirotaman terdapat permasalahan yang harus diselesaikan yaitu terdapat permasalahan umum dan permasalahan khusus. Oleh sebab itu perlu adanya metode pendekatan atau konsep dapat memecahkan permasalahan - permasalahan yang ada.

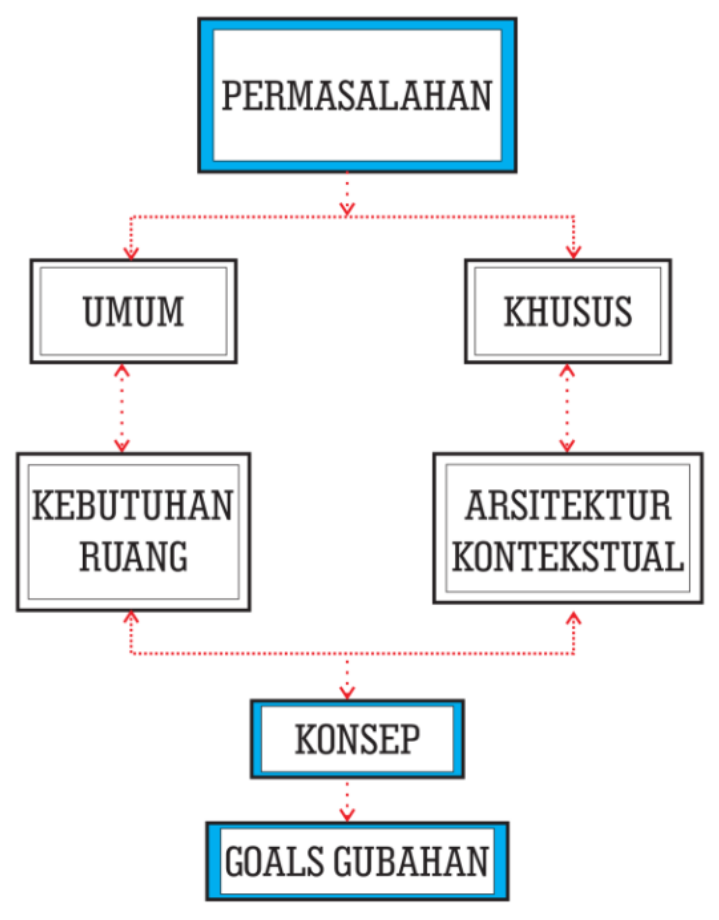

Gambar 2 Penyelesaian Desain

Penyelesaian desain dilakukan dengan menganalisis permasalahan umum yang merupakan perkembangan dan kebutuhan ruang kedepannya. Permasalahan khusus dimulai dengan identifikasi pendekatan arsitektur kontekstual lalu keduanya memunculkan konsep yang akan membentuk sebuah gubahan. 
Pembangunan Pasar Prawirotaman dimulai dari pendesainan ulang dengan mengelompokan jenis tempat dagang sesuai dengan kebutuhan, tentunya hal ini dimaksudkan supaya tercipta pasar yang rapi, nyaman seperti contoh :

1. Penataan ualang tempat berjualan dengan mengelompokan tempat yang didasarkan pada komoditas dan diharapkan dapat memudahkan pengontrolan utilitas bangunan, serta memudahkan pengunjung untuk mendapatkan barang sesuai yang dibutuhkan. Seperti menjauhkan tempat jual bahan kering dengan tempat berjualan yang banyak memerlukan air, mengelompokan lapak yang sesuai komoditi menjadi satu zona.

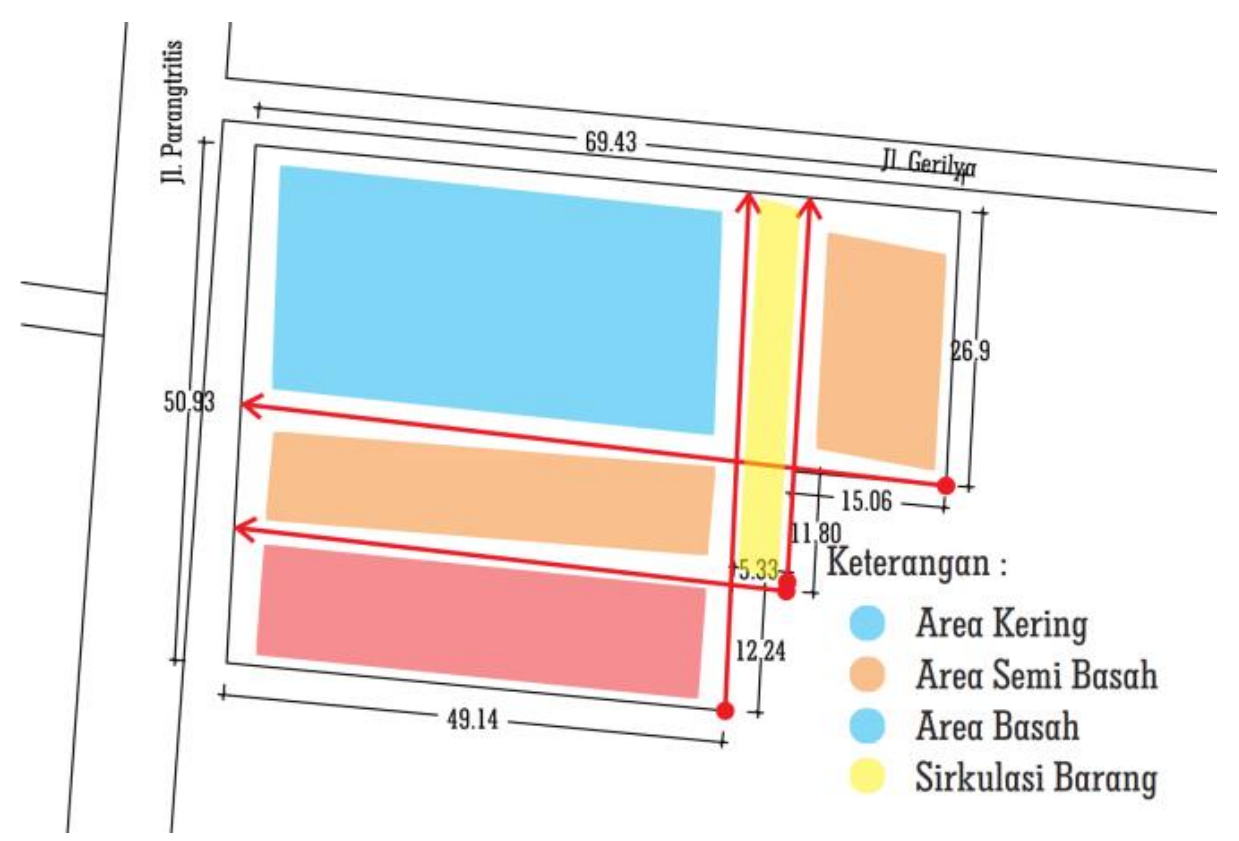

Gambar 3 Zona Pembagian Pasar

Sumber : Hasil Analisis Penulis, 2019

2. Perbaikan fisik dan struktur pasar dengan menggunakan material yang tahan lama dan kokoh serta mudah untuk perawatannya, sehingga mampu difungsikan dan memiliki umur yang panjang

3. Memperbaiki sirkulasi di dalam pasar dengan mempertimbangkan kenyamanan pembeli maupun penjual. Disamping itu penataan sistem drainase yang baik yang terintegrasi dengan sirkulasi di dalam pasar, untuk menjaga kebersihan dan kemudahan perawatan pasar.

4. Mampu menampung semua pedagang yang ada saat ini serta memungkinkan untuk pengembangan pasar kedepannya.

Aksesabilitas untuk masuk kedalam bisa di akses melaluli dua sisi pasar yaitu di sebelah utara dan di bangian barat. Sirkulasi digolongkan sesuai dengan kebutuhan dan fungsinya seperti akses masuk utama pasar berada di sisi barat dengan pintu masuk yang lebar.

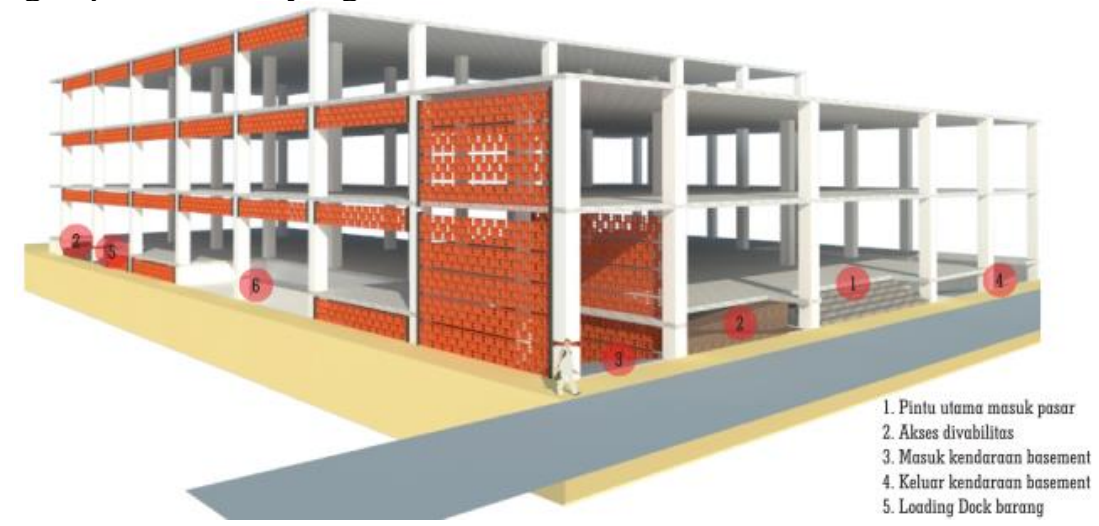

Gambar 4 Aksesabilitas Bangunan

Sumber : Hasil Analisis Penulis, 2019

1. Akses masuk utama Pasar dibuat dengan besar dan lebar supaya memudahkan pengguna yang akan masuk dan tidak akan berdesakan. 
2. Menyediakan akses divabilitas debgan penempatan di duasisi yaitu sisi utara dan sisi barat. Pemberian dua akses ini bertujuan supaya memudahkan penggunanya sehingga tidak harus memutar ataupun berbalik arah.

3. Masuk kendaraan kedalam basemen diletakan di sisi batart bangunan supaya memudahkan saat akan parkir kendaraaan

4. Pintu keluar kendaraan dari basement juga di letakan di sisi barat hal inni diperoleh dari analisis sirkulasi kendaraan yang dibuat satu lajur saja

5. Tersedia pintu atau akses masuk kedalam pasar yang ukuranya lebih kecil daripada pintu utama, ini ditujukan untuk memudahkan pengguna yang akan masuk melalui sisi utara pasrar

6. Penempatan loading dock berada di sisi utara, sebab kendaraan yang ada disana akan berhenti cukup lama dan apa bila diletakan di dekat jalan besar tentunya akan menimbulkan kemacetan nantinya.

Bangunan dibuat menghadap ke sisi barat sebagai muka utama dan sisi utara. Pembuatan dua muka sisi bangunan diperoleh dari hasil respon situasi yang menandakan di duasisi tersebut tersedia akses jalan uang bisa dilalui kendaraan, hal lain yang membuat perancangan menjadi dua sisi yaitu mempertahankan aksesabilitas psar yang lama.

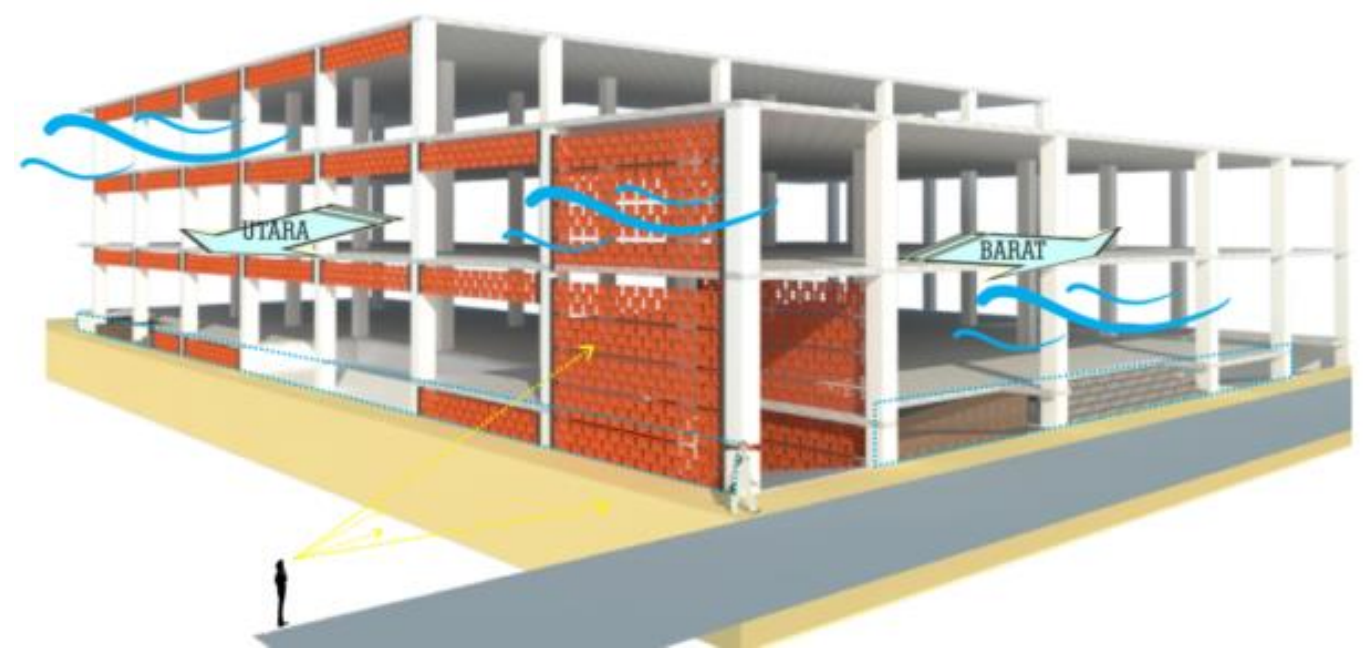

Gambar 5 Aksesabilitas Bangunan (

Sumber : Hasil Analisis Penulis, 2019 )

Selain itu lebih banyak menggunakan material bukaan seperti jendela, roster, dan raung yang tak memliki dinding supaya sirkulasi udara didalam pasar tetap baik dan tidak perlu penggunaan pendingin ruang. Mempermudak akses untuk mencapai bangunan dan keseluruhan ruang hal tersebut dilakukan guna mempermudah dan membuat orang suka serta nyaman berada ditempat tersebut. Penataan akses pejalan kaki atau penataan area pedestrian, memberikan layanan seperti tempat berhentinya kendaaran umun.

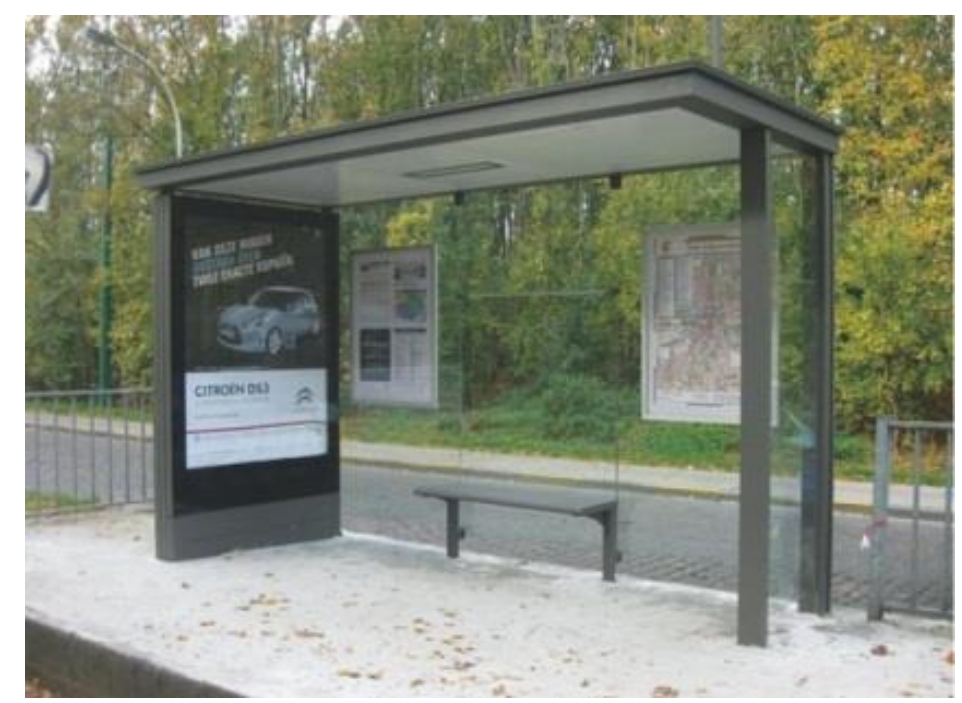

Gambar 6 Penyediaan Halte Bus 
Pemerian tempat pemberhentian kendaraan umum diletakan di dekan jalan utama sebelah selatan hal ini bermaksud supaya tidak menutupi akses pintu utama pasar namun masih mudah diakses bagi orang yang akan naik kendaraan umum, pemberian tempat duduk di lahan terbuka dan menyediakan tempat untuk pedagang kaki lima hal ini bertujuan supaya pengguna tidak merasa bosan saat menunggu kendaraan umum lewat ataupun jemputan.

Sebuah bangunan tentunya akan lebih nyaman jika memiliki pemandangan yang hijau. Konsep tata ruang hijau di pasar prawirotaman ini yaitu dengan memberikan grass block di sisi utara dan sisi barat muka pasar, rumput dan tanamah hias di sisi yang lain, dan tanaman yang bersifat meredam suara dan penyaring udara kotor dari kendaraan yang lewat.

Penggunaan grass block bertujuan supaya tidah terlalu becek jika terjadi hujan sebab jika diberikan material rumput saja pasti nanti akan berubah menjadi kubangan yang kotor dan nemengganggu lagipula air masih bisa meresap karena sifat grass block yang berlubang dibagian tengahnya.

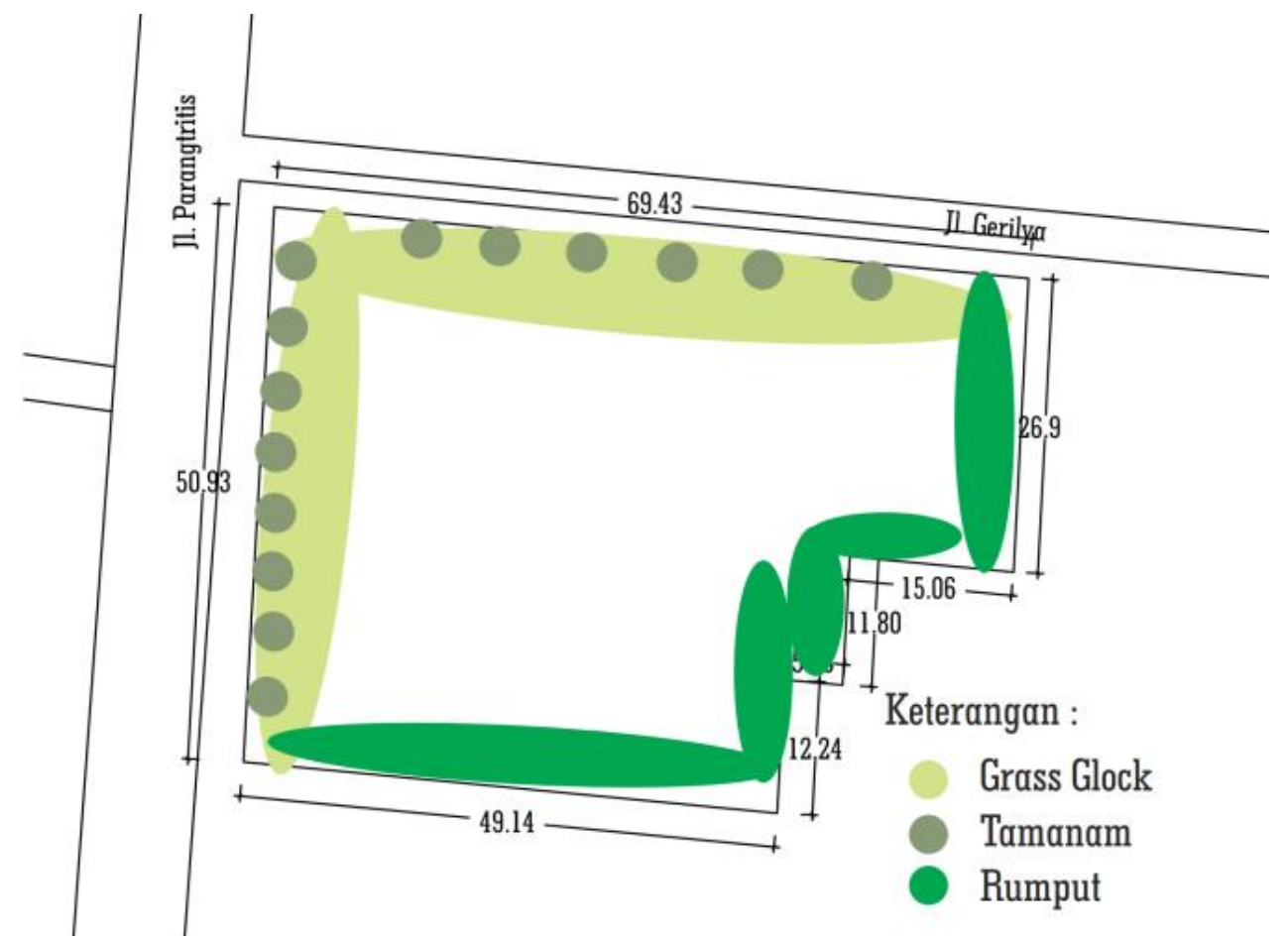

Gambar 7 Penataan Ruang Hijau

Sumber : Hasil Analisis Penulis, 2019)

\section{Kesimpulan}

Pasar menjadi tujuan utama masyarakat untuk berbelanja. Oleh sebab itu pemerintah harus mampu membantu akan ketersediaan lahan untuk didirikannya sebuah pasar. Pemerintah harus berperan penting tidak hanya dalam ketersediaan lahan, namun juga ketepatan lahan, fungsi, sarana dan prasarana juga harus mampu mewadahi segala kebutuhan masyarakatnya. Pada saat ini terutama pasar tradisisional makin banyak ditinggalkan peminatnya karena banyaknya pasar-pasar modern yang lebih memudahkan masyarakat untuk menggunakannya. Pasar tradisional sekarang dinilai kurang dari rasa nyaman, sering terjadinya penjambretan atau pencurian, lahan yang becek juga kotor mampu membuat orang akan berfikir dua kali untuk berbvelanja di tempat tersebut. Oleh sebab itu pemerintah harus mampu bekerja keras untuk mempertahankan adanya pasar tradisional dan menarik kembali masyarakat supanya merasa nyaman dengan fasilitas yang sudang mulai berkembang di jaman ini. Disinilah muncul gagasan saya untuk melakukan Revitalisasi Pasar dengan pendekatan Arsitektur Kontekstual sebagai pasar kreatif. Kontekstual Merupakan salah satu prinsip perancangan dalam arsitektur yang mempertimbangkan permasalahan desain dalam beberapa atau kesatuan bidang konteks. Tujuan utamanya adalah mengembangkan kembali pasar Prawitrotaman yang dulunya terlihat kotor, kurangnya pencahayan, kurang nyamannya di dalam pasar, bias menjadi pasar yang terasa nyaman,luas juga aman. 
Melalui desain pasar dengan pendekatan arsitektur kontekstual sebagai pasar kreatif bertujuan supaya mampu lebih memajukan pertumbuhgan perekonomian dan mampu memenuhi segala kebutuhan masyarakat. Dengan melakukan perencanaan ulang ini pasar yang tadinya hanya mampu beroperasi setengah hari kini mampu di kembangkan untuk hidup selama 24 jam, terutama dibidang kulinernya mengingat letak pasar yang berada di kawasan wisata atau kampong bule. Selain itu dengan ditambahnya unsur kreatif dalam perencanaan maka diharapkan mampu menjadikan pasar yang lebih dikenal luas lagi.

\section{Referensi}

(2007). Departemen Perdagangan, Pengaturan, Pengelolaan, dan Pengembangan Citra Pasar Tradisional Di Wilayah Perkotaan dan Perdesaan, 35-38.

A. A. (n.d.). Responsive Architectur. Ian Bentley.

Adhiatma Pradhipta, H. R. (2015). Penataan Pola Tata Ruang dalam Pasar Legi Tradisional Kota Blitar. http://arsitektur.studentjournal.ub.ac.id.

Aditya, I. (Senin, 30 Juli 2018). Pasar Prawirotaman Masuk Rencana Revitalisasi. Yogyakarta: krjogja.

Adrianto, S. A. (2004). Dinamika Kampung Kota. Yogyakarta: Departemen Pendidikan dan Kebudayaan Balai Pelestarian Nilai Budaya Yogyakarta.

Antoniades, A. C. (1990). Poetics of Architecture. John Wiley \& Sons.

Antoniades, A. C. (1992). Theory of Design. New York: Poetics of Architecture.

C.Poetics, A. (1992). Theory of Design. New York: Van Nostrand Reinhold.

Clovis Heimsath, A. (1977). Behavioral\& Architecture. McGraw-Hill.

David, D. \&. (1990). Developing Informal Retailing. London: Urban Markets.

Dirajo, M. B. (29 Jul 2018). Disperindag Yogya: Revitalisasi Pasar Prawirotaman Dibiayai Pusat. Yogyakarta: cendananews.

Endy Marlina, A. R. (23 June 2012). PASAR SEBAGAI RUANG PRIVAT MASYARAKAT. INTERNATIONAL SEMINAR \& NATIONAL SIMPOSIUM.

Hantono, D., Butudoka, Z., Prakoso, A. A., \& Yulisaksono, D. (2019). Adaptasi Seting Ruang Pasar Jiung

Terhadap Kehadiran Pasar Temporer Di Jalan Kemayoran Gempol Barat Jakarta. Jurnal Arsitektur ZONASI, 2(2), 75. https://doi.org/10.17509/jaz.v2i2.13628

Ischak, M., Setioko, B., \& Gandarum, D. N. (2018). Peran Place Identity Dalam Menciptakan Community Resiliance. Jurnal Arsitektur Zonasi, 1(2), 77-86. https://doi.org/http://10.17509/jaz.v1i2.12254

Mattorang, G. (2012, Desember Jum'at). Tinjauan Tentang Arsitektur . Retrieved oktober Rabu, 2018, from arsitektur .

Mattorang, G. (2012, Desember Jum'at). Tinjauan Tentang Arsitektur Kontekstual. Retrieved oktober Rabu, 2018, from arsitektur kontekstual: http://mattorang.blogspot.com/2012/12/tinjauan-tentang-arsitekturkontekstual.html

Mentri, P. U. (2010). Patent No. 18.

Oktavina, G. (2017-06-22). Redesain Pasar Tradisional Jongke, Surakarta. 123dok, II-26 - II-28.

Snyder, J. C. (1989). Pengantar Arsitektur. Jakarta: Erlangga.

Tri, (. (1 September 2018). Pasar Prawirotaman Akan Dibangun 4 Lantai. Yogyakarta: Harianmerapi.

Vitruvius, M. P. (1486). De Architectura. Romawi: Ten Books on Architecture.

Wijaya, Y. M. (1992). Wastu Citra. Indonesia: PT Prima Infosarana Media.

Peraturan Daerah Kota Yogyakarta. (2009). Peraturan Daerah Kota Yogyakarta Nomor 2 Tentang Pasar. Lembaran Daerah Kota Yogyakarta Tahun 2009 Nomor 25. 